REV. KAZIMIERZ PANUŚ

\title{
Annual Report of the President of the Polish Theological Society for 2012
}

The previous general meeting of the Polish Theological Society was held on 27 February 2012. The report for 2011 was presented and a vote of acceptance for the Board was conducted.

In the second part of the meeting HE abp. dr. Zygmunt Zimowski, the President of the Pontifical Council for Health Pastoral Care, was awarded the Medal of the Polish Theological Society. An official eulogy was given by HE abp. Wacław Depo, Metropolitan of Częstochowa. The celebration finished with a lecture of HM rev. prof. Henryk Skorowski SDB, the rector of the Cardinal Stefan Wyszyński University in Warsaw, entitled Christian versus Liberal Values. Concord or Discrepancy?

2012 was the second year of the activity of the Board, elected on 23 February 2011 to three-year term. Managing body composition:

B o a d

President: rev. prof. Kazimierz Panuś

Vice-President: rev. dr. habil. Roman Kuligowski (Associate Professor, Cardinal Stefan Wyszyński University)

Secretary: rev. Kazimierz Moskała, MA

Treasurer: rev. Andrzej Mojżeszko, PhD

Librarian: rev. dr. habil. Jan Bednarczyk

Publishing Committee Director: Sebastian Wojnowski, MA 
Controlling Committee

President: rev. prof. Tomasz Jelonek

Members: rev. Sylwester Jędrzejewski SDB, PhD; rev. Artur Kardaś $\mathrm{CR}, \mathrm{PhD}$

Fellow Members Arbitration Panel

President: rev. prof. Jacek Urban

Members: fr. prof. Tomasz Dąbek OSB, rev. dr. habil. Stanisław Hałas SCJ (Associate Professor, Pontifical University of John Paul II)

At the end of 2012 the Polish Theological Society had 890 members. In the reporting period 35 new members were accepted, including 21 members of the newly created department in Toruń. According to data collected, since the last general meeting the following people passed away: rev. Kazimierz Suder, fr. Letus Szpucha OFMBern, PhD, rev. Czesław Michalunio SJ, PhD, rev. prof. Stanisław Bielecki from Kielce, rev. Zdzisław Majcher (PhD in Canon Law) and rev. Stanisław Zygarowicz, PhD - both from the Przemyśl diocese.

Following the statutory regulations, in the reporting year the Board held four meetings: on 25 April 2012, on 25 September 2012, on 27 November 2012, on 26 February 2013.

During the first meeting a lecture of dr. habil. Tomasz Węcławowicz (Associate Professor, UPJPII), entitled Paratheological Interpretation of Art was presented. In the next part of the meeting the report of the President from the opening of two new field departments in Szczecin (8 December 2011) and in Torun (20 January 2012) was presented to the Board. The efforts aiming at broadening the Society's activity to other dioceses were discussed and the need of involving Seminary alumni was pointed out. The Board approved expert co-operation with the organiser of the International Exhibition of Church Construction, Church Fittings and Furnishings and Religious Art SacroExpo in Kielce.

The second Board meeting started with the lecture of rev. prof. Tomasz Jelonek concerning The Bible in the World of Myths. Next, rev. Pawel Borto's report on the co-operation with SacroExpo was presented. Board members participated in the opening of the $13^{\text {th }}$ International Exhibition 
of Church Construction, Church Fittings and Furnishings and Religious Art SacroExpo on 18 June 2012. During the trade fair opening members of the Society gave lectures on different aspects of religious art.

The Publishing Committee Director Sebastian Wojnowski informed the Board about the quarterly journal "Ruch Biblijny i Liturgiczny" evaluation results, which received 8 out of 10 points in the evaluation conducted by the Ministry of Science and Higher Education, thus becoming the highest ranked theological journal in Kraków, and the UNUM Press received a grant of 80,000 PLN in the INDEX PLUS 2012 contest for the project entitled Ruch Biblijny i Liturgiczny - Developing the International Character of the Journal. This was achieved due to the involvement of rev. Stanisław Wronka, PhD, the editor-in-chief and the Director of the Publishing Committee.

The third Board meeting began with the rev. dr. habil. Roman Sieron's lecture concerning Christian Education as the Antidote for the Educational Crisis of the Post-Modern Era - thoughts based on re-reading of the 'Gravissimum Educationis' Declaration on the 50 th Anniversary of the Second Vatican Council. Attempts to choose a new design of the membership certificate of the Polish Theological Society were made. A date and order of the general meeting were agreed upon.

The fourth statutory Board meeting was held on the day of the general meeting. It was devoted to the patronage of the Society over a new quarterly journal "Religious and Sacred Poetry, an International Quarterly of Religion, Culture and Education" prepared by Marek Mariusz Tytko, $\mathrm{PhD}$ (Jagiellonian University). The international scientific council of the quarterly consists of professors from 11 countries, including two Society members: s. dr. habil. Adelajda Sielepin (Associate Professor, UPJPII), and rev. dr. habil. Roman Bogacz. The design of the membership certificate of the Polish Theological Society, prepared by prof. Tomasz Węcławowicz, was approved. The financing of the application to the Ministry of Science and Higher Education concerning Science Popularisation, the website content and the scientific conferences organised by the Society were also discussed. 


\section{Society's Work}

The Sindonological Section, 15 specialised sections, 14 field departments and the Publishing Committee running the UNUM Press work within the Polish Theological Society.

The Sindonological Section of the Polish Theological Society is moderated by rev. dr. habil. Jerzy Chmiel. The Section is in contact with sindonologists abroad and provides information about the Shroud of Turin both for the press and the interested scientists.

\section{Specialised Sections}

Biblical Section. The Director of the Section is rev. dr. habil. Roman Bogacz. In the reporting year the Section held three meetings. The symposium entitled The Role of rev. prof. Tomasz Jelonek in the Formation of the Biblical Environment, which was held on 21 March, was of particular importance. Its aim was the celebration of the $75^{\text {th }}$ birthday of rev. prof. Tomasz Jelonek. Seven papers were presented: rev. prof. Waldemar Chrostowski showed the importance of rev. Jelonek for Biblistics in Poland; rev. prof. Anton Tyrol presented the contribution of rev. Jelonek and the Krakow community in the development of Biblistics in Slovakia; rev. Oleg Salomon and rev. Jacek Uliasz showed the development of Biblistics in Ukraine and the commitment of our biblicists, especially rev. Jelonek, in different activities, such as lectures in Lviv and Horodok, co-organisation of international conferences, assistance in training speakers and lecturers and the joint participation in the biblically-archaeological scientific camp in the Holy Land. In the second part of the session Tomasz Jelonek's contribution to interdisciplinary work was recognised, among others, on the links between Biblistics and Mathematics, as well as Biblistics and Natural Science. Tomasz Jelonek also stands out as the founder of the Laymen Theology College at the Faculty of Theology of the Pontifical University of John Paul II in Krakow, which inspired many to engage in deeper theological and biblical reflection.

Moral Theology Section, run by rev. Bogusław Mielec, PhD. In the reporting year the Section, in co-operation with other bodies (e.g. The 
Department of the Theology of Life of the Pontifical University of John Paul II in Krakow, Pastoral Care of Businessmen and Employers Talent), organised two conferences: 17 May 2012 - Moral Responsibility of Business People and 18 October - The Calling of a Business Leader. Material from both conferences was published by the UNUM Press.

Homiletic Section. The Director of the Section is rev. prof. Kazimierz Panuś. In the reporting year the Homilectic Section devoted a lot of attention to rev. Piotr Skarga SJ. Due to his 400th death anniversary, this great preacher, writer and polemicist was announced by the Parliament of the Republic of Poland one of the patrons of 2012. Due to that fact, on 26 January 2012, during the $21^{\text {st }}$ symposium for retreat preachers, priests and priestly confessors held by the Episcopal Commission on Clergy in Jasna Góra, the Section Director presented a lecture on Piotr Skarga - a Model Priest. The second presentation devoted to the great preacher took place during 29th Week of Christian Culture in Trzcianka. On 23 April 2013 the Director of the Homiletic Section lectured on Piotr Skarga as the Master of Ars Oratoria. The Homiletic Section Director participated in the celebration of the $70^{\text {th }}$ birthday anniversary of rev. prof. Władysław Głowa, a member of the Polish Theological Society. During this conference, which was held at the John Paul II Catholic University of Lublin (KUL) on 10 October 2012, the Section Director presented a paper entitled: "Manifests through us the odor of the Knowledge of him" (2 Cor 2:14). On Important Issues Concerning the Proclamation of the Word of God.

Sociologically-Pastoral Section. This Section, run by rev. Stefan Dobrzanowski, $\mathrm{PhD}$, consists of 22 scientists in the field of sociology, Catholic social science and pastoral theology, working mainly in Krakow, Warszawa and Lublin. In the reporting year the Section organised two sessions. The first one, held on 14 October, concerned mainly organisational issues connected with the session devoted to the growth of aggressive atheism among politicians and religious indifference among the youth. The second meeting took place on 23 November in the Order of Carmelites in Krakow. Two lectures were presented during this meeting. Prof. Franciszek Adamski elaborated on: The Growth of Atheism in Contemporary Democracy as a Challenge for the Church in Poland, and Paweł Chmura, PhD, discussed the problem of The Image of the Church 
in the Eyes of the Youth in the Post-Industrial Environment of Pabianice. Both issues turned out to be extremely up-to-date and resulted in long and interesting discussions. They revealed a rapid process of secularisation of the Polish society, the decreasing influence of the Church and family values on the young generation of Poles and the lack of respect for the rules and teachings of the Church and John Paul II among politicians declaring to be Catholics.

Section of Spirituality. The Director of the Section is rev. prof. Wojciech Misztal. The Section continued working on the academic research program concerning The Spirituality of Polish Orders: Message and Communication. The works of the Section resulted in organising two symposiums: Fr. Hieronim Kajsiewicz CR (1812-1873): Care about Spirituality - Care about the Well-Being of the Society (Krakow, 28 February 2012) and "She was given a great charism by the Holy Spirit" (John Paul II). St. Urszula Ledóchowska and the Congregation of the Ursulines of the Agonizing Heart of Jesus (Łódź, 19 May 2012). Material from the conferences was published. The representatives of the Polish academic circles, both laymen and clergy, participated in the realisation of these projects, due to the integration of the academic world and better understanding of the potential of both the Pontifical University of John Paul II in Krakow and the Polish Theological Society.

Pedagogically-Catechetical Section. The Director of the Section is rev. prof. Janusz Mastalski. In the reporting year the Section actively participated in the organisation of two conferences: How to Build the Authority of a Teacher (Krakow, March 2012) and Awareness of Raising (May 2012). The Section also organised a panel meeting during which the discipline problems in contemporary schools were discussed.

Dogmatic Section. The Director of the Section is rev. dr. habil. Jan Żelazny (Associate Professor, UPJPII). In the reporting year the Section admitted new members from different academic institutions in Poland. The members of the Section organise regular monthly meetings concerning research on Christian antiquity.

Missiological Section. The Section works in co-operation with the Polish Association of Missiologists and the Papal Missionary Works of the Diocese of Katowice, under the supervision of rev. Grzegorz 
Wita, PhD. Monthly meetings were held by the Section as part of Open Missiological Seminars, during which different current practical and theoretical issues concerning evangelisation were touched on. All meetings began with the celebration of the Eucharist for the intentions of realising the Church mission. The Section continued working on the project The Young are the Church's Future in co - operation with the Missionary Works in Katowice. The aim of the project is providing support for educational centres in the Near East, Eastern Europe, Africa and South America. Their efforts resulted in organising (for the third time) a two-week retreat for the Moldovan youth from around Kishinev, Moldova. The retreat was conducted by the students of the Department of Theology of the University of Silesia. In the spirit of solidarity with the Christians from the Holy Land, a project entitled Rosary Mission Bridge was organised. The project enhanced understanding of the universality of the Church and the sense of responsibility for her. In the first quarter of 2012 a Missionary Competition was held. It concerned the life and works of Pauline-Marie Jaricot, the founder of the Association of the Living Rosary and the Society for the Propagation of the Faith. The competition was addressed to primary school students (artistic works) and grammar school students (literary works) and resulted in 470 works from 65 schools and institutions. The majority of works was sent from the diocese of Katowice, but also from around Gliwice, Opole, Zielona Góra and Gorzów. The effort made resulted in greater involvement in the activity of the Papal Missionary Works, as well as the creation of the Living Rosary roses. On 21 April the Missionary Congress of the Katowice Archdiocese was organised in Mikołów, with more than 500 participants. Different lectures and missiological discussions for different age groups were held. On 16 June the $10^{\text {th }}$ Missionary Rally of the Papal Missionary Works of the Katowice Archdiocese (Bielsko-Biała-Szczyrk-Brenna) was organised with the co-operation of the Section members. The rally had more than 200 participants, with its main theme being the situation of the Church in Moldova. From 10 to 12 September in Wigry, a Missiological Conference organised by the Polish Association of Missiologists was held. The members of the Missiological Section took part in the conference and were again elected to the Board of the Association. On 10 October 
2012 the first pilgrimage of the rosary circles in the history of the archdiocese was organised. During the pilgrimage rev. Grzegorz Wita, $\mathrm{PhD}$, presented a speech on The Brilliant Simplicity of the Works of PaulineMarie Jaricot as the Inspiration for the Contemporary Church. On 30 November 2012 the Section Director participated in the International Conference on Missiology and New Evangelisation in Contemporary Europe (Cardinal Stefan Wyszyński University), where he presented his lecture on Association of Polish Missiologists as a Platform of Communication and Integration of the Scientific Research. On 25 November the Second Synod of the Katowice Archdiocese was opened, and rev. Grzegorz Wita was nominated the President of the Evangelisation Committee. Some Section members participated in the meetings of missionary and missiological circles; some books and articles connected with the work of Section members were published.

Canon Law Section. Directed by fr. Andrzej Kukła CSsR, PhD. In the reporting year the members of the Section participated in a few important symposiums, e.g.: the Polish Scientific Conference Church Advocate - who is that? (John Paul II Catholic University of Lublin KUL, 18 April), the $6^{\text {th }}$ International Conference on Media Ethics Values in the Media - the Value of the Media (Pontifical University of John Paul II in Krakow, 31 May-1 June), International Scientific Conference of Canonists Parish in the Canon Law and in the Polish Law (Gdańsk, 10-11 September), the $12^{\text {th }}$ Conference on the Role of the Catholic Church in the Process of European Integration (Krakow, 14-15 September). One Secion meeting connected with the presentation of the lecture of fr. dr. habil. Marek Saj CSsR, the lecturer of the Cardinal Stefan Wyszyński University, was held.

Liturgical Section. The Section is run by rev. Stanisław Mieszczak $\mathrm{SCJ}, \mathrm{PhD}$. In the reporting year the members of the Section worked for the sake of the liturgical service formation. The meetings of the Section members were a response to current pastoral problems and helped prepare for the visitation of the painting of Merciful Jesus in the parishes of the Krakow archdiocese. The Liturgical Section holds meetings of Liturgy lecturers and priests, especially the ones most involved in the process of liturgy renewal, giving them opportunities for discussions and the exchange of experiences. 
Sacred Art Section. The Section is run by dr. habil. Tomasz Węcławowicz (Associate Professor, UPJPII). In the reporting year the Section's activity focused on scientific and popular science presentations concerning the historical content of religious architecture. On 25 April the Director of the Section presented a lecture during the Board meeting. Another important presentation of the Section's Director was a lecture on Iconographic Tradition in Christian Art given on 18 June in Kielce during the Conference associated with the International Exhibition of Church Construction, Church Fittings and Furnishings and Religious Art Sacro Expo. From 6 to 7 December the Sacred Art Section in co-operation with the Institute of the History of Art and Culture of the Pontifical University of John Paul II organised the $2^{\text {nd }}$ International Scientific Conference entitled Between the Medieval Symbol and the Modern Allegory. Section members, dr. habil. Andrzej Włodarek (Associate Professor, UPJPII) and dr. habil. Tomasz Węcławowicz (Associate Professor, UPJPII), chose the guests invited from abroad, got and kept in touch with them and acted as translators during the discussion itself. Moreover, the Director of the Section prepared a graphic design of the Society's membership diploma.

Philosophical Section. The Director of the Section is rev. dr. habil. Henryk Majkrzak SCJ. In the reporting year three meetings accompanied by discussions were organised: on 2 March about Healthy Philosophy for Christian Europe based on the article of bp. prof. Ignacy Dec; on 23 March about the Sense of Dealing with Philosophy (based on the article of fr. prof. Mieczysław Krąpiec) and on 30 April about the interpretation, meaning and up-to-date aspects of Seneca's Dialogue Of Peace of Mind (De tranquilitatae animi). The Director of the Philosophical Section had a book published (The Doctor of Doctors. Saint Thomas Aquinas, Kęty 2012, 272 pp.). The Section accepted two new members from Olsztyn and Lublin.

Fundamental Theology Section. The Section is run by rev. Damian Wąsek, PhD. In the reporting year the Section hosted or co-hosted many events of scientific character, with special emphasis put on the ecumenical and apologetic context. Their most important achievements of this year are: Ecumenism - a Threat or the Consequence of Faith? - a scientific session organised by rev. prof. Łukasz Kamykowski; 
The Kingdom of God and the Church - a symposium organised by prof. Andrzej Napiórkowski OSPPE; lectures: Piste per proseguire la ricerca alla luce di Gesù Abbandonato in Chiara Lubich (Loppiano, Sophia, Instituto Universitario) and Ecclesiology of John Paul II in Chosen Wednesday Catecheses (Rome, The Centre for Documentation and Research of the Pontificate of John Paul II) given by rev. prof. Łukasz Kamykowski and Theology and Other Sciences given by the Section's Director rev. Damian Wąsek, $\mathrm{PhD}$, at the Adam Mickiewicz University in Poznan during the conference entitled On the Rules of Current Theology. The afore-mentioned events were preceded by the meetings and consultations of the Section members. The discussions on main issues of fundamental theology were held. A number of books and scientific articles were published by the members of the Section.

Historical Section. The Section is directed by rev. prof. Józef Marecki. The Section did not hand in the annual report for 2012.

\section{Field Departments}

Katowice Department. The works of the Department, which currently has 19 members, are directed by rev. dr. habil. Andrzej Nowicki. In the reporting year two meetings were held. The first one, held on 3 April in the Archdiocese Museum in Katowice, was attended by the members of the Department, as well as media and culture representatives. During the meeting a lecture entitled The Heart as a Credible Criterion of Salvation was given by rev. dr. habil. Andrzej Nowicki. The second meeting of the Katowice Department took place on 26 October during the conference concerning card. August Hlond, the patron of 2013. During the conference the paper on The Social Issue in the Pastoral Care Program of Card. August Hlond was presented by rev. prof. Jan Górecki.

Częstochowa Department. The Department is run by rev. Jerzy Bielecki, PhD. In the reporting year two Department Board meetings were held. A symposium organised on 1 December on the $50^{\text {th }}$ Anniversary of the Second Vatican Council was an important event. The following papers were presented: The Church and the Man's Calling in the "Gaudium et spes" Constitution (abp. Zygmunt Zimowski, $\mathrm{PhD}$ ), The Revelation and 
the Obedience in Faith in the Light of the "Dei Verbum" Constitution (rev. dr. habil. Janusz Królikowski), Marian Dimension of the Church in the "Lumen Gentium" Constitution (rev. Teofil Siudy, PhD), Post-Conciliar Reform of the Eucharistic Liturgy in Accordance with the "Sacrosanctum Concilium" Constitution (fr. Piotr Polek OSPPE, PhD), Co-Responsibility of the Church for the Education of the Young Generation as a Message of the "Gravissimum Educationis" Declaration (rev. Jerzy Bielecki, PhD) and Decree "Inter mirifica" - the Conciliar Impulse for the Evangelisation through the Media of Social Communication (abp. Wacław Depo, PhD). Material from the symposium will be published in March 2013 in the 40 $0^{\text {th }}$ issue of "Częstochowskie Studia Teologiczne." The symposium was broadcast by the internet TV of the "Niedziela" weekly, and later saved on CDs.

Przemyśl Department. The Department is directed by rev. dr. habil. Wacław Siwak. In the reporting year three meetings were held; during each meeting a paper was presented: on 16 February Biblical Sources of the Rosary Misteries: Annunciation and Visitation by rev. Wacława Siwak, $\mathrm{PhD}$; on 7 June The Development of the Monastic Theology after the Council of Chalcedon by rev. Arkadiusz Jasiewicz, PhD, accompanied by the presentation of the book Święty Jan Klimak, Drabina raju [St. John Climacus. The Ladder of Divine Ascent] (Kęty 2011), the introduction to which was written by the speaker himself, and on 29 November Peace and Truth in the (Post) Modernist, Globalised World by rev. Norbert Podhorecki, PhD.

Kalwaria Zebrzydowska Department. Run by fr. dr. habil. Romuald Kośla OFM. In the reporting year the Kalwaria Zebrzydowska Department organised two meetings. On 23 March a scientific session entitled The Issues Concerning the Second Edition of "Preparation to Studies in Church Archives" was held in Kalwaria Zebrzydowska, the following papers were presented: Genesis of Monography (rev. prof. Anzelm Weiss), The Portrait of the First Edition Author (fr. Aleksander K. Sitnik OFM, $\mathrm{PhD}$ ), Scientific Achievements of Hieronim E. Wyczawski OFM (fr. dr. habil. Wiesław Murawiec OFM), Organisation of the Church in Poland after 1992 (rev. Tomasz Moskal, PhD), Polish Church Archives after 1989 (rev. dr. habil. Mieczysław Różański), Monastic Archives in Poland. Changes between 1990 and 2011 (fr. prof. Roland Prejs OFMCap). The second Department meeting took place on 8 November during the academic 
year 2012/2013 inauguration in the Bernardine Theological College in Kalwaria Zebrzydowska. During the celebration a lecture on Christian Family Upbringing According to rev. Piotr Poręba was given by fr. Roman Banasik OFMConv, PhD.

Tuchów Department. Run by fr. Janusz Urban CSsR, PhD. In the reporting year the Tuchów Department co-organised a pastoral symposium entitled New Evangelisation - the Spring of the Church (25-27 January), during which rev. dr. habil. Andrzej Witko (Associate Professor, UPJPII) presented the message and the foundations of the cult of Divine Mercy as well as the figures of St. Faustina and John Paul II as witnesses of Divine Mercy; rev. prof. Andrzej Zwoliński discussed current pastoral challenges in the light of social Church teaching and its significance for the new evangelisation, and bp. dr. habil. Grzegorz Ryś presented the new evangelisation as shown in the pre-conciliar document concerning new evangelisation Lineamenta and indicated the tasks the Church in Poland is facing. From 24 to 29 September the Days of the Redemptorist Formation were celebrated, and from 6 to 8 November homiletic workshops in Tuchów took place. The workshops were organised by fr. Antoni Karaś, $\mathrm{PhD}$, the lecturer of the Redemptorist Theological College in Tuchów, and its main theme was connected with the Year of Faith. Their aim was preparing sermon outlines that could be used in the forthcoming year of apostolic work. Three meetings were held, during which plans for the semester were discussed.

Kielce Department. Run by rev. Paweł Borto, PhD. In the reporting year the Department organised regular, monthly meetings, during which the Members exchanged experiences and information on different scientific conferences and cultural events. During the meeting in February rev. Paweł Borto presented a report on the works concerning the edition of The New Herder's Biblical Lexicon, in the promotion of which card. Gianfranco Ravassi participated during the 1st Biblical Congress (29 October 2011). During the meeting in April rev. Zbigniew Trzaskowski outlined the program of co-operation of the theologians in Kielce with the Faculty of Humanities of the Jan Kochanowski University. The meeting in May was devoted to the preparation of the Sacrum in Culture Conference, which took place on 18 June 2012, opening the $13^{\text {th }}$ Sacro-Expo Trade Fair 
in Kielce. During the conference papers were presented by the following people: dr. habil. Tomasz Węcławowicz (The Iconographic Tradition in Christian Art), dr. habil. Tadeusz Boruta, and Krystyna Stawecka, PhD, curator, historian, museologist and the Director of the Museum of Icons in Supraśl. During the October meeting the Department Director presented a publication entitled Christian Witness Today, edited by himself and rev. Daniel Swend as part of the Theologia Radomiensia series (vol. 2, Radom 2012). The work contains conference material under the same title, from a conference which took place in 2010 in Kielce and Radom. The content of studies presented in the book was the subject of a heated discussion among the participants.

Sandomierz Department. The Department is run by rev. dr. habil. Roman Bogusław Sieroń (Associate Professor, KUL). There are 27 people in the Department, working with the Wincenty Kadłubek Theological Institute in Sandomierz. In the reporting year many forms of activity were initiated by the Department members. Six international conferences were organised or co - organised: Around Christian East (Sandomierz, 21 April), The Value of Christian Upbringing (Stalowa Wola, 23 April), Cultural Changes in the Changing Society (Stalowa Wola, 22-23 May), Suffering, Dying and Death - Looking for Value and Meaning (Stalowa Wola, 19 June), Family Care (12 May) and The ChristianJewish Relations in History, Art and Memory. The European Context of the Sandomierz Cathedral Works of Art (11 January 2013). With the cooperation of the Department two national conferences were organised as well: Man in the Teachings of Blessed John Paul II (Stalowa Wola, 13 October) and a student conference The Formation of Catholic Intelligence in the $21^{\text {st }}$ Century (Stalowa Wola, 23 May). During the meeting of the Department members on 12 December a lecture on Contemporary Moral Dilemmas in the Year of Faith was given by rev. Waldemar Olech, $\mathrm{PhD}$, vice-headmaster of the Theological College in Sandomierz and member of the Polish Theological Society.

The members of the Sandomierz Department participated in 27 national and international scientific conferences, giving lectures or chairing sessions. The intensive publishing activity of the Department members resulted in 24 books and articles, mostly printed by a year's issue of "Studia 
Leopoliensia," "Przegląd Biblijny," "Kronika Diecezji Sandomierskiej," and the quarterly "Społeczeństwo i Rodzina. Stalowowolskie Studia Katolickiego Uniwersytetu Lubelskiego Jana Pawła II," which received 7 out of 10 points in a recent evaluation of the Ministry of Science and Higher Education for each of the presented articles.

Tarnów Depart me nt. Rev. dr. habil. Janusz Królikowski (Associate Professor, UPJPII) is the Director of the Department. In the reporting year the Tarnów Department continued working on the research concerning the history of the Diocese of Tarnów, inspired by the 225 Anniversary of its creation. The works resulted in another volume of studies devoted to the history of the Tarnów Diocese, this time concerning the people who participated in its creation. It is entitled The History of the Diocese of Tarnów, vol. 3: People of the Church. It comprises of 27 articles, mainly written by the Society members, but also by the researchers of Church history from outside Tarnów. As a fourth volume of this series, The Chronicle of the Seminary from 1934 to 1939, has been prepared for printing .

Apart from the publishing works, in November 2012 a scientific conference devoted to anti-clericalism was organised in Mielec. The conference was inspired by the $100^{\text {th }}$ Anniversary of the Pastoral Letter of bp. Leon Wałęga concerning this important Church, social and cultural issue. Five papers were presented. The conference material is being prepared for printing.

Rzeszów Departme nt. The Department Director is rev. dr. habil. Andrzej Garbarz, Associate Professor of the University of Rzeszów. In the reporting year the Department members initiated different projects promoting the development of theological thought as well as made efforts to counteract the processes of dechristianisation and social secularisation. Among their initiatives there were regular formative and organisational meetings and various scientific conferences organised by the Department: Women in the Contemporary World (Rzeszów, 13 March), Towards Better Understanding of the Holy Scripture (Myczkowce, 12 May), On the Polish-Slovakian-Ukrainian Border. Religions - Beliefs - Rites (Myczkowce, 13 October), The Bible - the Book of Faith (Kolbuszowa, 16 November), Witnesses of Faith of the Catholic Church in the Contemporary World (Michałówka, 1 December), Contemporary Faces of Manipulation 
(Rzeszów, 13 December) and one exhibition entitled The Prison Years of Primate Stefan Wyszyński 1953-1956 (Rzeszów, 20 June).

Bielsko-Biała Department. Run by rev. prof. Tadeusz Borutka. The Department has 47 members. In the reporting year three meetings took place at the premises of St. John Cantius Theological Institute in Bielsko-Biała: on 10 January 2012 - Christmas meeting for the members of the Department and the academic world of Podbeskidzie, with participation of bp. Tadeusz Rakoczy; on 15 May - a lecture on Stanisław Hozjusz Theory of Reformation given by rev. Robert Samsel, PhD, St. John Cantius Theological Institute in Bielsko - Biała; on 4 December 2012 - a lecture on From Hell to the Hope of Salvation. The Development of the Issue of Salvation of Non-Baptised Children's Death in the Catholic Theology and Its Existential Importance given by Marta Ficon, $\mathrm{PhD}$, St. John Cantius Theological Institute in Bielsko - Biała. All lectures were followed by discussions.

Rad om D e part m e nt. Run by rev. Dariusz Zbigniew Skrok, PhD. In the reporting year the Department, currently consisting of 61 members, co-organised two scientific conferences: Saint Giles and the Mystery of Life (10 November) in the St. Giles parish in Sucha k. Pionek and Catechesis in the Service of Faith - the Year of Faith (27 October) in Radom with the papers on: The Second Vatican Council as the Answer to the Signs of Time (rev. dr. habil. Marek Jagodziński, Associate Professor of the Card. Stefan Wyszyński University), The Catechism of the Catholic Church as the Origin of the Content of Faith (ks. dr Marek Dziewiecki), Christian Calling as the Experience of Faith (rev. Jarosław Wojtkun, PhD), Faith in Dialogue with Culture (rev. Piotr Turzyński, PhD), The Needs and Possibilities of Faith Justification in Christian Life (rev. Daniel Swend, PhD), Witnesses of Faith in the Catechetical Message (rev. dr. habil. Adam Maj, Associate Professor of KUL), Sharing Faith in Contemporary Church Practice (rev. dr. habil. Wiesław Przygoda, Associate Professor of KUL) and Upbringing in Faith as the Main Task of Catechesis (rev. dr. habil. Stanisław Labendowicz, Associate Professor, Card. Stefan Wyszyński University).

Sosnowiec Department. The Department, which currently has 36 members, is run by rev. prof. Jan Orzeszyna. In the reporting year four meetings were held: two days of meditation, one board meeting and one academic meeting to discuss the defended doctoral thesis. 
The days of meditation were connected with the celebration of the liturgical year. On the first lent day of meditation (24 March 2012) a penitential service, examination of conscience and confession were offered. Rev. Marek Studenski, PhD, gave a lecture entitled The Art of Upbringing.

On the second advent day of meditation (1 December 2012) a conference of rev. Piotr Madeja, father divine of the Theological College of the Diocese of Sosnowiec, entitled The Meeting of the Catechist with God as the Basis of New Evangelisation took place, together with the concelebrated mass presided by rev. Marek Sendal, the Dean of Nowy Sącz Deanery (the sermon was delivered by rev. Andrzej Stasiak, the Dean of the Dąbrowa Górnicza Deanery).

On 5 June 2012 the members of the Sosnowiec Department participated in the academic meeting concerning the doctoral thesis of rev. Michał Borda entitled The Biblical Concept of Calling in the Post-Grammar School Catechesis and its Reception by Students (based on research among last year students of secondary schools in the Diocese of Sosnowiec). The paper touches on current problems concerning the understanding of the biblical concept of calling in the post-grammar school catechesis among the last year students of secondary schools. On the basis of different literary works, collected research data and the author's observations conclusions were reached and catechetical postulates formulated. The aim of the thesis was an attempt to come up with practical ideas to enhance the effectiveness of education in post-grammar school catechesis.

On 21 September 2012 a board meeting of the Sosnowiec Department took place. Due to the celebration of the Year of Faith in the parishes of the Diocese of Sosnowiec on one Sunday of the month before every mass catecheses for adults concerning fundamental Church issues will be read. The Sosnowiec Department of the Polish Theological Society prepared a short catechesis on the so-called registered partnership and its ethical and moral evaluation. It opposed the promoting campaign for the recognition of same gender registered partnership. The Board sent Christmas and Easter wishes to all the members of the Department.

Szczecin Department. It was created on 8 December 2011 and works at the Faculty of Theology of the Szczecin University. In the first year of its activity the Department organised four scientific 
symposiums. On 30 May, in co-operation with the Faculty of Church History and the Faculty of Pastoral Theology, a regional conference on the $825^{\text {th }}$ Anniversary of St. James' Church Consecration - the cathedral of the Archdiocese of Szczecin and Kamien (1187-2012) was held. The employees of the National Archives in Szczecin participated in the conference. From 18 to 19 June, in co-operation with the Faculty of Catechetics of the Theological Department of the University of Szczecin, the Szczecin Department organised two-day debates on: Religion Teacher - Catechist in the Contemporary Polish Reality ( $1^{\text {st }}$ session: Theological Context: catechist - witness of faith, educator and religion teacher; $2^{\text {nd }}$ session: Educational and Catechetical Context: educational teacher requirements; models of catechist positioning in Church regulations and $3^{\text {rd }}$ session: Sociologically-Cultural Context: post-modernist tendencies; the changes in students' and teachers' mentality under the influence of the media). Abp. prof. Andrzej Dziegga, metropolitan of Szczecin and Kamień, as well as bp. Marek Mendyk, the President of the Polish Episcopate Committee for Catholic Education, were among the conference participants. On 17 November in the seminary a scientific conference as a part of the Year of Faith entitled The Past and Present of the Second Vatican Council took place. Six papers were presented and information on the Polish Theological Society was provided. One of the 87 participants of the conference was bp. Edward Dajczak, the ordinary officer of Koszalin and Kołobrzeg. The papers will be printed in "Colloquia Theologica Ottoniana" 2 (2012). On 30 November, on the $60^{\text {th }}$ Anniversary of the cardinal nomination of Primate Stefan Wyszyński, with the participation of the National Archives in Szczecin and the Faculty of Church History of the Theological Department, a scientific symposium was organised on Cardinal Stefan Wyszyński-Memory and Gratitude of Western Pomerania. The following papers were presented: rev. prof. Zygmunt Zieliński (John Paul II Catholic University of Lublin KUL): Card. S. Wyszynski in the Expanse of the Universal Church and in Poland, rev. dr. habil. Grzegorz Wejman, Associate Professor of the Śląsk University: Card. S. Wyszyński in the Process of Church Organisation in Western Pomerania, prof. K. Kozłowski (University of Szczecin): The Role of Card. Wyszynski in the Process of Polonisation 
in the Areas by the Baltic Sea and the Oder, Tadeusz Krawczak, PhD, (Archiwum Akt Nowych [the Archive of New Records] in Warsaw): Social and Religious Activity of Card. Wyszynski in the Collections of Archiwum Akt Nowych and rev. Grzegorz Chojnacki, PhD, (University of Szczecin): Primate Stefan Wyszyński and the Youth. The scientific session was preceeded by the jubilee celebration of rev. prof. Andrzej Offmański. The following people participated in the celebrations: the Metropolitan of Szczecin and Kamień abp. Andrzej Dzięga, rectors of the Cardinal Stefan Wyszyński University rev. prof. S. Dziekoński and the University of Szczecin prof. Edward Włodarczyk, the dean of the Faculty of Theology of the Adam Mickiewicz University in Poznań rev. prof. Jan Szpet, the Faculty of Theology of the University of Szczecin rev. prof. Henryk Wejman; the dean of the Faculty of Humanities of the University of Szczecin dr. habil. Barbara Kromolicka; the dean of the Faculty of Physics and Mathematics of the University of Szczecin prof. Piotr Krasoń, as well as many Associate Professors of the University of Szczecin, rev. prof. Kazimierz Panuś, the President of the Polish Theological Society and rev. prof. Zbigniew Marek, the President of the Polish Catechists Association.

The Department in Tor un is the newest of all Field Departments. It was created on 20 January 2012. It is run by rev. dr. habil. Dariusz Zagórski, Associate Professor of the Mikołaj Kopernik University in Torun. The Torun Department of the Polish Theological Society coorganised two events: on 21 March a symposium on the $20^{\text {th }}$ Anniversary of the creation of the Diocese of Torun, during which the following papers were presented: The Diocese of Torun and its Continuation of the Great Heritage (prof. Wiesław Sieradzan), Caritas Ministry in the Diocese of Torun (rev. Daniel Adamowicz, MA), Movements and Associations of the Laity in the Diocese of Torun (dr. habil. Waldemar Rozynkowski, Associate Professor of the Mikołaj Kopernik University) and Charisms and the Apostolate of Orders in the Diocese of Torun (s. Elżbieta Sozańska, PhD); and from 18 to 20 October the scientific conference on The Fundaments of Medieval Europe. The symposium material on the $20^{\text {th }}$ Anniversary of the creation of the Diocese of Torun has already been published. 


\section{Final Remarks}

One of the most important achievements of the Board of the Polish Theological Society is the co-operation with the International Exhibition of Church Construction, Church Fittings and Furnishings and Religious Art SACROEXPO. It allows the Society members to inspire and participate in the creation of the contemporary religious art. Another significant achievement is receiving funds from the INDEX PLUS 2012 competition, which made the project entitled Ruch Biblijny i Liturgiczny - Developing the International Character of the Journal possible. Thanks to establishing two new Field Departments in Szczecin and Torun in the last few years, the Polish Theological Society managed to spread its activity to all parts of Poland. We hope that current negotiations will result in creating more field departments.

The Departments in Kielce, Sandomierz and Sosnowiec, as well as Krakow's Biblical, Fundamental Theology, Sacred Art and Missiological Sections should receive special recognition for all their accomplishments. It is also worth mentioning that in the reporting year 35 new Society members were accepted.

The Polish Theological Society is a public Polish association. We wish to thank card. Stanisław Dziwisz as well as the bishops present at the General Meeting and the Polish Episcopal Conference for the care of the Church authorities for the development of the Society. The Board would also like to thank all active members of the Society, who, despite various difficulties, spare no effort to continue the works of the Society, making the Polish community more sensitive to theological thought. 
